\title{
Evaluation of Mechanical Properties and Microstructures of Molybdenum and Niobium Microalloyed Thermomechanically Rolled High-Strength Press Hardening Steel
}

\author{
JAAKKO HANNULA, ${ }^{1,2}$ DAVID A. PORTER, ${ }^{1}$ ANTTI KAIJALAINEN, ${ }^{1}$ \\ and JUKKA KÖMI ${ }^{1}$ \\ 1.-Materials and Mechanical Engineering, Faculty of Technology, University of Oulu, P.O. Box 4200,
} 90014 Oulu, Finland. 2.—e-mail: jaakko.hannula@oulu.fi

This article studied the effect of molybdenum and niobium on the microstructures and mechanical properties of laboratory control rolled steels based on grade $22 \mathrm{MnB} 5$. The constructed continuous cooling transformation diagrams revealed that an addition of Mo significantly increased the hardenability. Especially in the case of austenite compressed below its recrystallization temperature, an Mo addition delayed ferrite and bainite formation, and it increased martensite hardness. Laboratory hot-rolling experiments with a finish rolling temperature of $850^{\circ} \mathrm{C}$ produced a flattened pancaked austenite. After hot rolling and direct quenching, samples were rapidly reaustenitized at $900^{\circ} \mathrm{C}$ followed by water quenching to simulate an actual press hardening process. Especially in the case of Nb-Mo steel, a strongly pancaked austenitic structure was achieved after hot rolling, which led to a fine, uniform prior austenite grain structure after re-austenitization and quenching. The $\mathrm{Nb}-\mathrm{Mo}$ steel had a tensile strength $>1500 \mathrm{MPa}$ and $\sim 11 \%$ total elongation combined with good impact toughness, which can be considered excellent for this type of press hardening steel.

\section{INTRODUCTION}

The use of ultra-high strength steels, such as transformation induced plasticity (TRIP), dual phase (DP), complex phase (CP) and press hardening steels (PHS), has substantially increased in automotive applications mainly because of increased passenger safety, weight reduction, improved part functionality and fuel efficiency. ${ }^{1}$ However, in the lifting, handling and transportation industries, for example, press hardening is not widely used, mainly because of the modest toughness properties. Similar difficulties are to be expected when increasing strength by using higher carbon contents.

Despite the development of the press hardening process itself, the most widely used steel in press hardening is still 22MnB5, which has remained practically unchanged since the 1970 s. It was originally developed for use as a low-cost wear-resistant steel in agricultural equipment, when customer demands were totally different from those today.
The beneficial effect of microstructural refinement on the toughness of martensitic steels has been verified by many studies. ${ }^{2-5} \mathrm{Nb}$ microalloying can be beneficial for achieving a more finely grained structure because of its ability to control austenite grain size during reheating and refine grain size during deformation.v It is also known that $\mathrm{Nb}$ and Mo by themselves can improve the hardenability of the steel by supressing the ferrite formation by reducing the carbon diffusivity and exerting a strong drag force on the moving grain boundaries. ${ }^{7}$ For example, the effect of Mo on delaying the ferrite formation is approximately three and six times stronger than that of alloying elements, such as Mn and $\mathrm{Ni}^{8}$ Mo and $\mathrm{Nb}$ alloying can also improve hardenability in boron alloyed steels by increasing the amount of soluble boron at the grain boundaries. This is caused by the suppression of $\mathrm{Fe}_{23}(\mathrm{C}, \mathrm{B})_{6}$ precipitates by $\mathrm{Nb}$ and Mo alloying. ${ }^{9}$

Also alloying with combined additions of $\mathrm{Nb}$ and Mo is known to have synergetic influences providing more benefits than the sum of the effects of $\mathrm{Nb}$ and 
Mo alone. For example, Mo by itself does not have any significant impact on static recrystallization (SRX) behavior during hot rolling, but a combination of Mo and $\mathrm{Nb}$ leads to a synergistic increase in the retardation of SRX. ${ }^{10}$ In this research, the target is to see the effect of $\mathrm{Nb}$ and $\mathrm{Nb}-\mathrm{Mo}$ alloying on the mechanical properties of a 22MnB5-based composition.

\section{EXPERIMENTAL}

\section{Materials and Heat Treatment}

The two materials used in the present investigation were medium-carbon $(\sim 0.22$ wt.\%) steels containing nominally equal amounts of manganese $(\sim 1.2$ wt.\%), silicon $(\sim 0.2$ wt.\%), chromium $\sim 0.2$ wt.\%), niobium ( 0.05 wt.\%), titanium and boron and two levels of molybdenum: $0 \mathrm{wt} . \%$ and $0.16 \mathrm{wt} . \%$. Each steel was named after the contents of $\mathrm{Mo}$ and $\mathrm{Nb}$, producing markings of $\mathrm{Nb}$ steel and $\mathrm{Nb}-\mathrm{Mo}$ steel. The steels were vacuum cast into approximately $70-\mathrm{kg}$ slabs at the Tornio Research Centre of Outokumpu in Finland; $180 \times 80 \times 55$ $\mathrm{mm}$ pieces of the castings were homogenized at $1200^{\circ} \mathrm{C}$ for $2 \mathrm{~h}$ and thermomechanically rolled to approximately 8-mm-thick plates using six passes with approximately $20 \%$ reduction in each pass. The temperature of the samples during rolling was monitored by thermocouples placed in holes drilled in the edges of the samples to the mid-width at midlength. The finish rolling temperature (FRT) was $850^{\circ} \mathrm{C}$, after which the rolled strips were direct quenched using water quenching. The hot rolled samples were re-austenitized at $900^{\circ} \mathrm{C}$ for 5 -min holding time followed by water quenching [cooling rate $(\mathrm{CR}) \sim 80^{\circ} \mathrm{C} / \mathrm{s}$ ] to simulate an actual press hardening process.

\section{CCT Diagrams}

Dilatation tests for constructing continuous cooling transformation (CCT) diagrams were carried out using a Gleeble 3800 thermomechanical simulator for generating the phase transformation data as a function of cooling path. The purpose for constructing CCT diagrams, with and without deformation, was to find the critical cooling rates to form a fully martensitic microstructure, which is needed for the actual press hardening process. Also the effect of Mo and Mo-Nb alloying on hardenability can be evaluated by comparing constructed CCT diagrams. Cylindrical specimens with dimensions of $6 \mathrm{~mm}$ diameter $\times 9 \mathrm{~mm}$ height were machined from solution-treated and water-quenched laboratory rolled samples. Two types of dilatation tests were conducted: with or without prior strain. In the case of straining, samples were heated at $10^{\circ} \mathrm{C} / \mathrm{s}$ to $1150^{\circ} \mathrm{C}$, held for $2 \mathrm{~min}$, cooled to $850^{\circ} \mathrm{C}$, held $10 \mathrm{~s}$ and then compressed with three hits each having a strain of $\sim 0.2$ at a strain rate of $1 \mathrm{~s}^{-1}$. The time between hits was $25 \mathrm{~s}$. The specimens were then held $25 \mathrm{~s}$ prior to cooling at various linear rates in the range of $10-50^{\circ} \mathrm{C} / \mathrm{s}$ (Fig. 1a). For comparison, another set of specimens was reheated in a similar manner, cooled at $2^{\circ} \mathrm{C} / \mathrm{s}$ to $1000^{\circ} \mathrm{C}$ and held for 2 min prior to continuous cooling at different rates (Fig. 1b).

\section{Mechanical Properties}

Longitudinal tensile tests and Charpy- $\mathrm{V}$ impact tests were performed to evaluate the strength and low temperature toughness properties, respectively. Tensile tests were performed using flat specimens with $8 \mathrm{~mm}$ thickness according to the ISO 68921:2009 standard. ${ }^{11}$ Charpy- $\mathrm{V}$ impact tests were performed at various temperatures (2 specimens/ temperature) according to the European standard EN 10 045-1:1990 ${ }^{12}$ to derive the Charpy V-transition curves using $5 \times 10 \times 55$-mm specimens.

\section{Microstructural Characterization}

Microstructural characterization was executed using light microscopy (LM) and field-emission scanning electron microscopy combined with electron backscatter diffraction (FESEM-EBSD). The linear intercept method applied to laser scanning confocal microscopy (LSCM) images from directquenched specimens etched with saturated picral in a soap solution was used to determine the prior austenite grain sizes in two principal directions - the rolling direction (RD) and strip normal direction (ND) - at the quarter thickness of the specimen. Based on these measurements, average grain sizes in RD and ND directions and total reduction below the recrystallization temperature $\left(R_{\text {tot }}\right)$ were calculated.

EBSD measurements and analyses were performed using the EDAX-OIM acquisition and analysis software. FESEM for the EBSD measurements was operated at $15 \mathrm{kV}$ using a step size of $0.15 \mu \mathrm{m}$. Lath and effective grain sizes were determined as equivalent circle diameter (ECD) values with low$\left(2.5-15^{\circ}\right)$ and high-angle boundary misorientations $\left(15-62.8^{\circ}\right)$, respectively.

\section{RESULTS AND DISCUSSION}

\section{CCT Diagrams}

Figure 2 presents the constructed CCT diagrams of the investigated steels with and without deformation. Maximum hardness values of the fully martensitic microstructure were 460-471 HV10 without deformation and 490-504 HV10 with deformation, the Nb-Mo steel having slightly higher hardness values. Minor differences can be noticed when comparing the CCT diagrams without deformation. With the slowest cooling rate of $10^{\circ} \mathrm{C} / \mathrm{s}$, the Mo addition decreased the amount of bainite from $\sim 40 \%$ to $\sim 15 \%$, giving a higher hardness value of 425 HV10 compared with 351 HV10. 


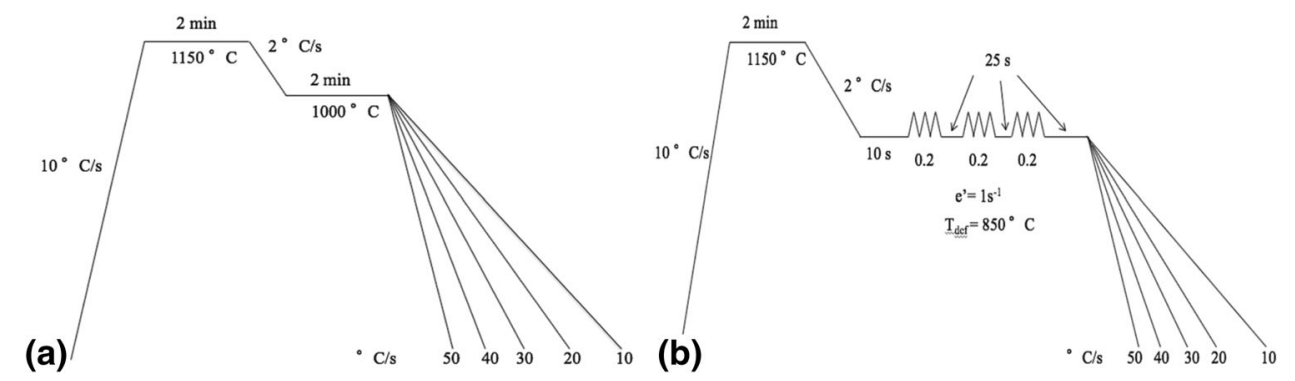

Fig. 1. Gleeble simulation procedure for constructing CCT diagrams: (a) undeformed; (b) deformed.
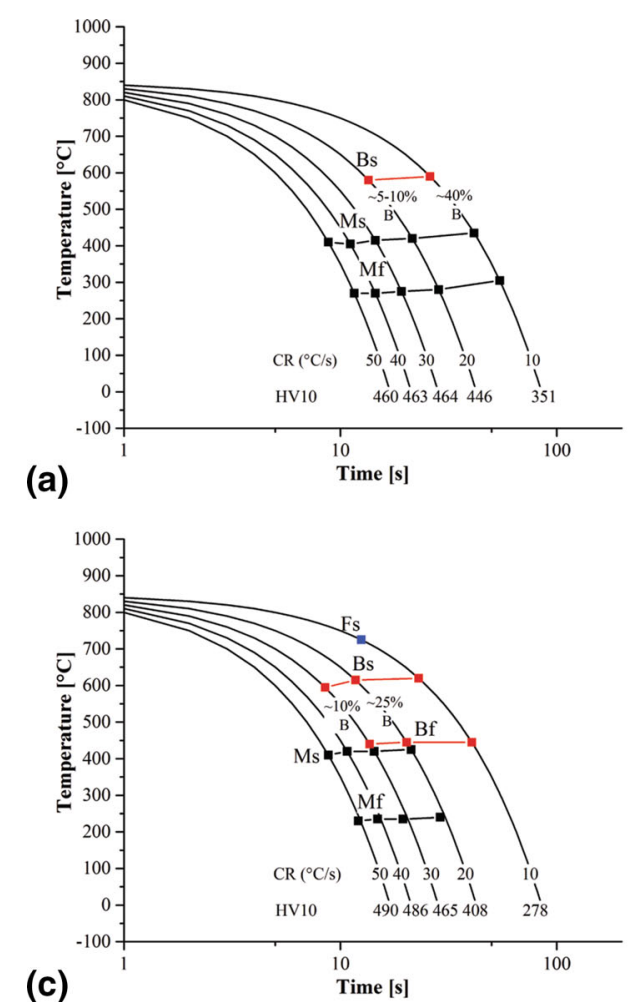

(b)

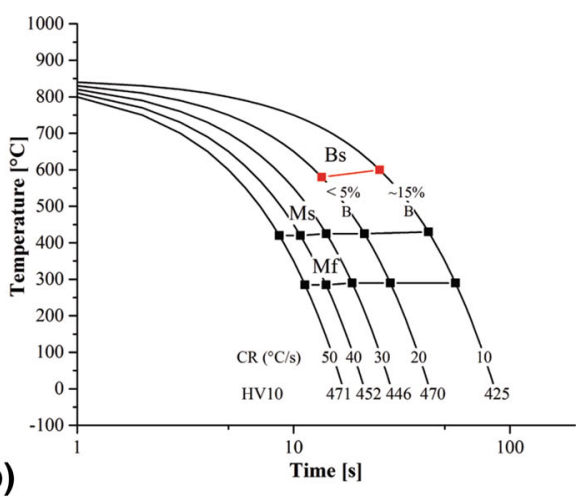

(d)

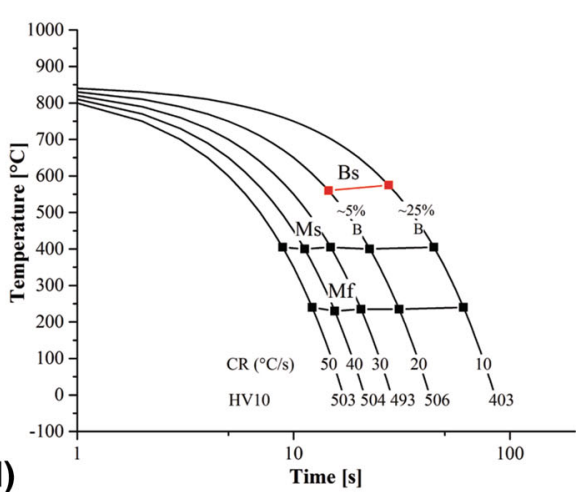

Fig. 2. CCT diagrams of investigated steels. (a) Nb steel, no deformation; (b) Nb-Mo steel, no deformation; (c) Nb steel, deformation $3 \times 0.2$; (d) $\mathrm{Nb}-\mathrm{Mo}$ steel, deformation $3 \times 0.2$.

Comparing CCT diagrams with deformation (Fig. 2c and d), it can be seen that the Mo addition had a more significant effect on the phase transformation kinetics. In the presence of Mo, the formation of ferrite was prevented when cooling at $10^{\circ} \mathrm{C} / \mathrm{s}$ (403 HV10 versus 278 HV10) and the martensite fraction was increased, giving a hardness of 506 $\mathrm{HV} 10$ even at a cooling rate of $20^{\circ} \mathrm{C} / \mathrm{s}$. Deformation accelerated the formation of ferrite and bainite, leading to lower hardness values at the lower cooling rates. Mo addition delayed ferrite/bainite formation, thereby leading to a wider range of cooling rates able to form fully martensitic microstructures. Based on the CCT diagrams for deformed specimens, the $\mathrm{Nb}$ steel requires a cooling rate of approximately $30-40^{\circ} \mathrm{C} / \mathrm{s}$ to produce a fully martensitic microstructure, whereas the $\mathrm{Nb}-\mathrm{Mo}$ steel requires only $\sim 20^{\circ} \mathrm{C} / \mathrm{s}$. Earlier studies have shown that soluble $\mathrm{Nb}$ has a stronger effect on lowering the transformation temperatures compared with precipitated $\mathrm{Nb} .^{13}$ The effect of Mo on lowering the transformation temperatures and producing higher hardness values in $\mathrm{Nb}$-alloyed steel can be due to molybdenum's ability to increase the solid solubility of $\mathrm{Nb}$ in the austenite, which produces lower transformation temperatures, increasing the amount of bainite and decreasing the amount of ferrite with lower cooling rates. ${ }^{13,16}$

Figure 3 presents microstructures seen after the CCT tests with $3 \times 0.2$ deformation. The microstructure of the $\mathrm{Nb}$ steel with a cooling rate of $10^{\circ} \mathrm{C} / \mathrm{s}$ (Fig. 3a) was a mixture of bainite and ferrite giving a hardness of 278 HV10, whereas the Nb-Mo steel had a more lath-type microstructure of bainite/martensite with a hardness of 403 HV10 

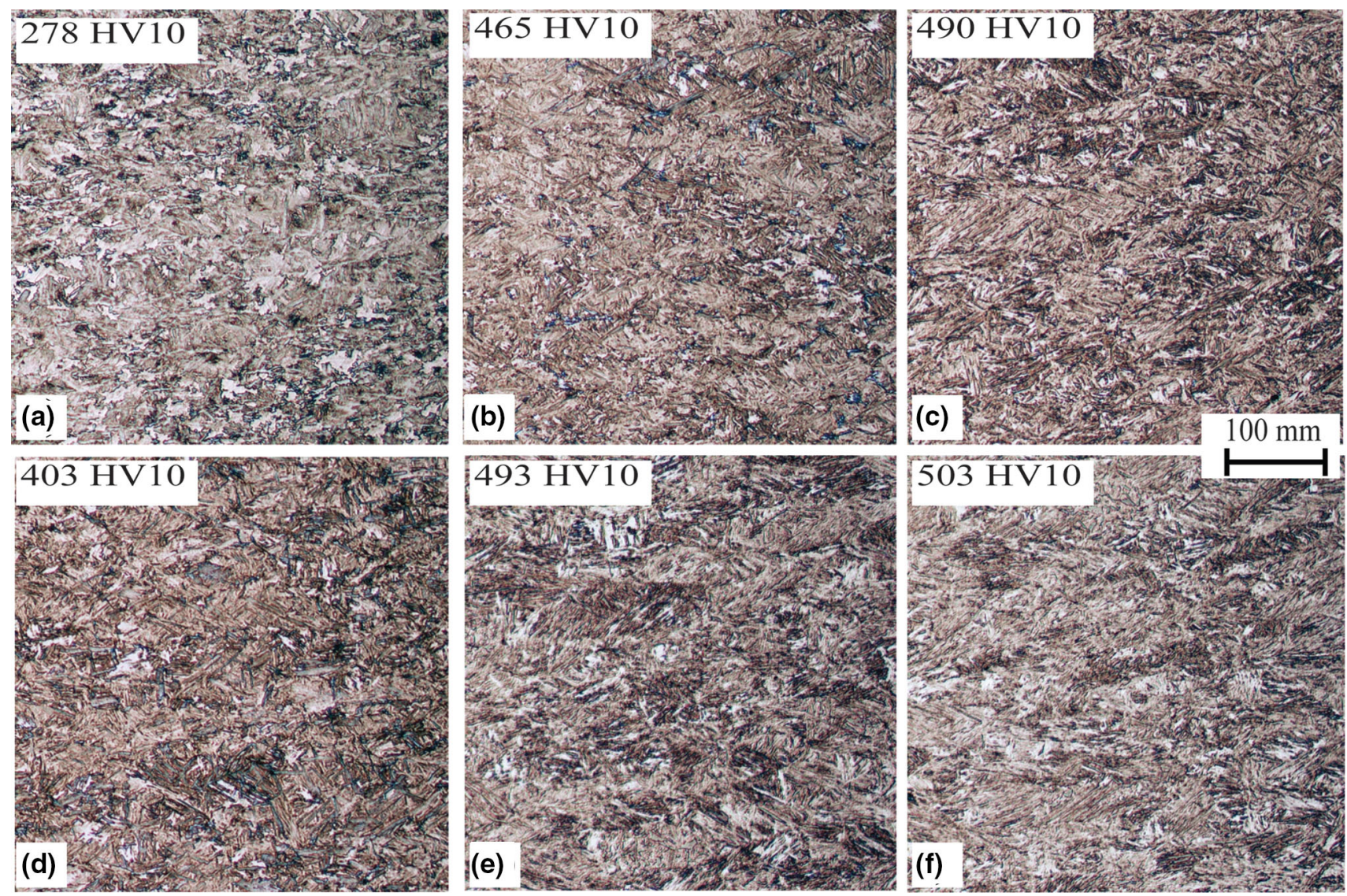

Fig. 3. Microstructures (LM) after CCT tests with $3 \times 0.2$ deformation. Cooling rates from left to right: $10^{\circ} \mathrm{C} / \mathrm{s}, 30^{\circ} \mathrm{C} / \mathrm{s} \mathrm{and} 50^{\circ} \mathrm{C} / \mathrm{s}$. $(\mathrm{a}-\mathrm{C}) \mathrm{Nb}$ steel; (d-f) Nb-Mo steel.

(Fig. 3b). Moving toward higher cooling rates, the fraction of martensite is increased in both steels.

\section{Prior Austenite Grain Structure After Hot Rolling}

Table I shows the measured austenite grain sizes in two principal directions and corresponding $R_{\text {tot }}$ values after hot rolling and direct quenching. The $\mathrm{Nb}-\mathrm{Mo}$ steel produced a more pancaked austenite structure, which can be seen as higher $d_{\mathrm{RD}}$ and $R_{\mathrm{tot}}$ values in Table I. Based on previous studies, it can be concluded that the effect of $\mathrm{Nb}$ on retarding the recrystallization process is stronger in the presence of Mo. ${ }^{14,15}$ During hot rolling in the austenite region, carbon diffusion activation energy increases as the content of Mo increases, which means that the carbon diffusivity decreases. ${ }^{16}$ Also Mo alloying, as mentioned earlier in the text, in the Nb-containing steel can increase the solubility of the $\mathrm{Nb}(\mathrm{C}, \mathrm{N})$ phase in the austenite and also increase the solid solubility of the $\mathrm{Nb}$ element in the austenite. ${ }^{16}$ Soluble $\mathrm{Nb}$ is known to be more effective, retarding the dynamic recrystallization process, and precipitated $\mathrm{NbC}$ prevents more effective static recrystallization. ${ }^{16,17}$ The present results confirm that $\mathrm{Nb}$ Mo alloying has a stronger effect on delaying the
Table I. Average austenite grain sizes in two principal directions after hot rolling and direct quenching $\left(d_{\mathrm{RD}}, d_{\mathrm{ND}}\right)$, corresponding austenite reduction percentage below the recrystallization temperature $\left(\boldsymbol{R}_{\text {tot }}\right)$ and average grain size after reaustenitization and quenching ( $d_{\text {re-aust }}$ )

\begin{tabular}{|c|c|c|c|c|}
\hline Steel & $\underline{d_{\mathrm{RD}}(\mu \mathrm{m})}$ & $\underline{d_{\mathrm{ND}}(\mu \mathrm{m})}$ & $R_{\text {tot }}(\%)$ & $\underline{d_{\text {re-aust }}(\mu \mathrm{m})}$ \\
\hline $\mathrm{Nb}$ & 9.6 & 5.7 & 22.6 & 7.4 \\
\hline Nb-Mo & 14.0 & 5.3 & 38.4 & 6.9 \\
\hline
\end{tabular}

recrystallization than $\mathrm{Nb}$ alloying by itself, which could be caused by the synergy effect with $\mathrm{Nb}$ and Mo. Figure 4a shows the elongated prior austenite grain structure of Nb-Mo steel after hot rolling and direct quenching.

Table I also presents the prior austenite grain sizes $\left(d_{\text {re-aust. }}\right)$ after rapid re-austenitization and water quenching to simulate the actual prior austenite grain sizes after press hardening. Both investigated steels had a relatively small prior austenite grain size after re-austenitization and quenching (7.4 $\mu \mathrm{m}$ and $6.9 \mu \mathrm{m})$; see Fig. $4 \mathrm{~b}$. 

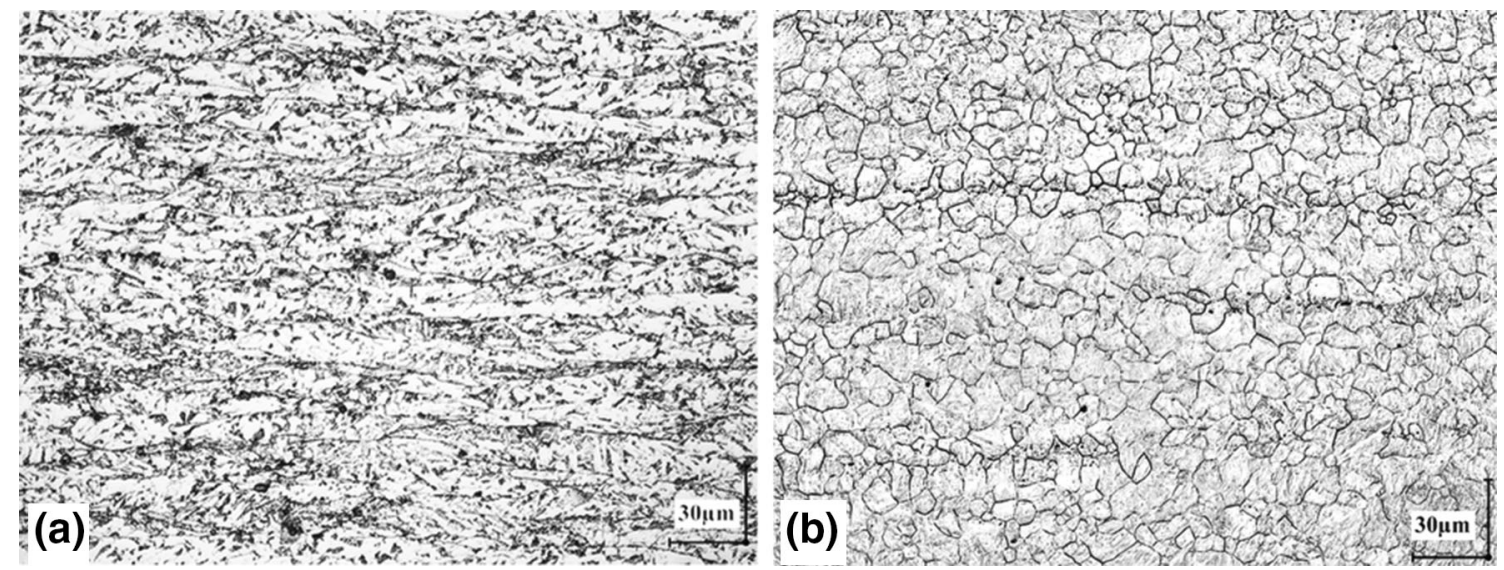

Fig. 4. Prior austenite grain boundaries of Nb-Mo steel after (a) hot rolling and direct quenching (FRT $\left.850^{\circ} \mathrm{C}\right)$; vb) after further re-austenitization and quenching.
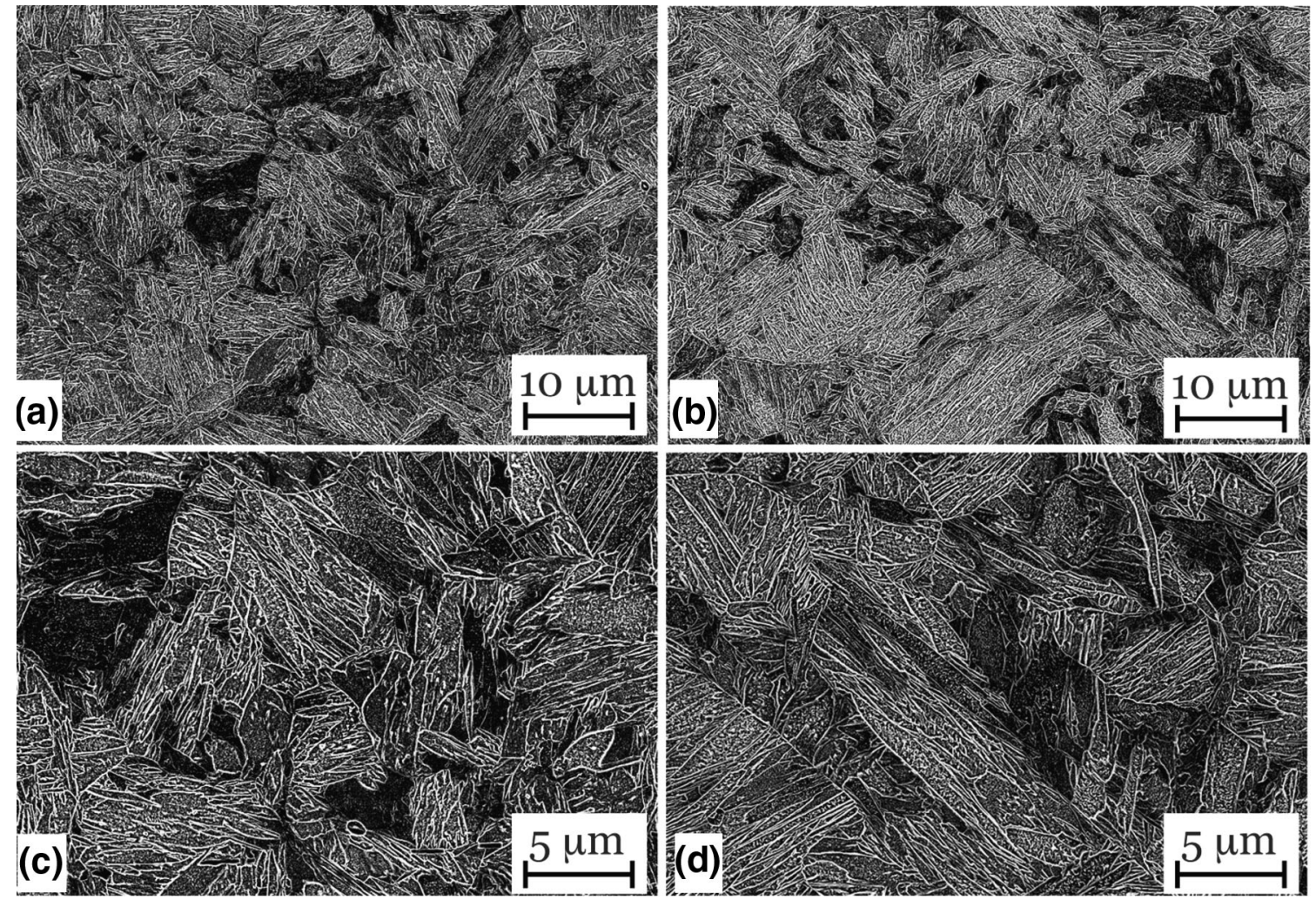

Fig. 5. Typical microstructures (FESEM after etching in $2 \%$ nital) of investigated steels after re-austenitization. (a, c) Nb steel; (b, d) Nb-Mo steel.

\section{Transformed Microstructure}

Figure 5 shows typical microstructures of the investigated steels after re-austenitization at $900^{\circ} \mathrm{C}$ and water quenching at the $1 / 4$ depth position of the samples. Generally, the microstructures consisted of fine packets and blocks of martensitic laths randomized in different directions. Self-tempering of the martensite also occurred, which can be seen as very fine carbides within the martensite laths (Fig. 5c and d).
The microstructures of the investigated steels were further characterized using EBSD after reaustenitization and are presented in Fig. 6. The mean effective grain and lath sizes were determined as equivalent circle diameter (ECD) values with low- $\left(3-15^{\circ}\right)$ and high-angle boundary misorientations $\left(>15^{\circ}\right)$. Also, the 90th percentile effective high-angle grain sizes (d90\%) were determined. The results, presented in Fig. 6e, revealed that a slightly finer and more uniform martensite grain structure was achieved in the Nb-Mo steel. Nb-Mo 

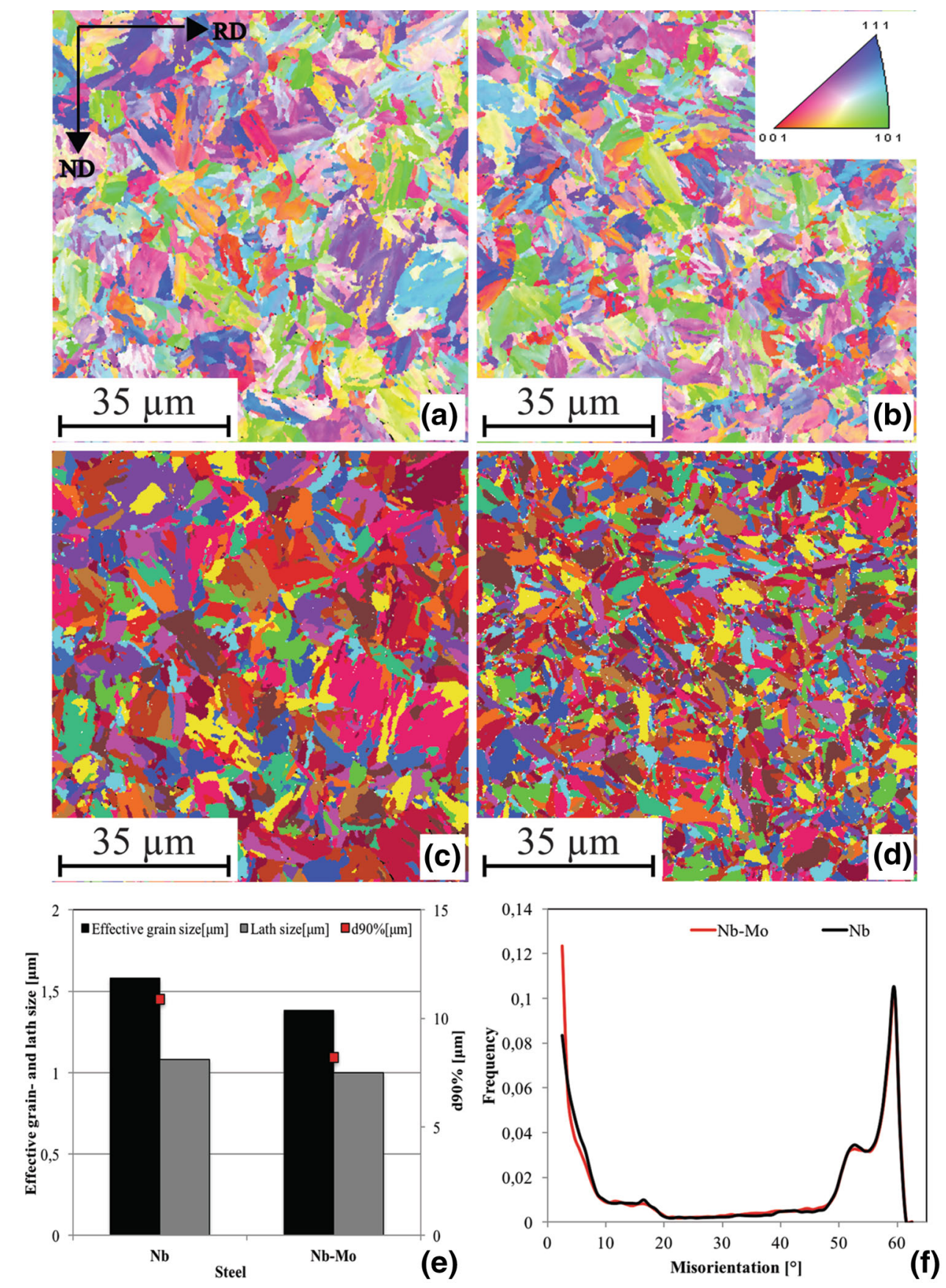

Fig. 6. Based on EBSD analysis: Inverse pole figures (upper row) and grain maps (lower row) of investigated steels after hot rolling and direct quenching. (a, c) Nb steel; (b, d) Nb-Mo steel. (e) The effective grain and lath sizes and the size of the coarsest grains (d90\%); (f) grain boundary misorientation distributions $\left(>2.5^{\circ}\right)$.

microalloying led to a small decrease in the mean effective grain and lath sizes, presumably because of the more pancaked austenite structures. Also, $\mathrm{Nb}$ Mo microalloying led to a smaller d90\% grain size, indicating a more uniform prior austenite structure.

Also grain misorientation angle distributions were determined using the EBSD data, and the results are presented in Fig. 6f. Misorientation peaks at $\sim 7.5^{\circ}, 16^{\circ}, 52.5^{\circ}$ and $59^{\circ}$ were detected, which are a result of the different variants of the
Kurdjumov-Sachs orientation relationship. High peaks at $\sim 7.5^{\circ}$ (sub-block boundaries) and $\sim 59^{\circ}$ (packet or/and block boundaries) are characteristics of martensite. ${ }^{18,19}$ Based on misorientation distributions, no clear differences between the different steels were apparent, which confirms the conclusion from the other microstructural studies that the investigated steels comprised mainly martensite.

Inverse pole figures (IPF) and grain maps are presented in Fig. $6 \mathrm{a}$ and d. Comparing the grain 
maps in Fig. $6 \mathrm{c}$ and $\mathrm{d}$ shows that a clearly finer grain structure is achieved in the $\mathrm{Nb}-\mathrm{Mo}$ steel, which confirms the grain size results from the EBSD analyses.

\section{Mechanical Properties After Hot Rolling, Direct Quenching and Re-austenitization}

The measured yield stress values $\left(R_{\mathrm{p} 0.2}\right.$, i.e., $0.2 \%$ offset proof stress) varied in the range 1108$1147 \mathrm{MPa}$, tensile strength values in the range $1510-1537 \mathrm{MPa}$ and total elongation to fracture values in the narrow range 10.7-11.2\%. Uniform elongation values were between $4 \%$ and $4.4 \%$ and can be considered high for $\sim 1500 \mathrm{MPa}$ steel. Stress-strain curves from tensile tests are presented in Fig. 7b. The Nb-Mo steel achieved slightly higher strength values combined with slightly higher elongation values.

The hardness profiles through the thickness of the tested materials are presented in Fig. 7a. Both steels had a robust microstructure through the thickness, producing hardness values in the range of 501-519 HV10, which correlates well with the measured tensile strength values.

Transition curves were constructed based on Charpy-V impact test results obtained in the temperature range of $+80^{\circ} \mathrm{C}$ to $-80^{\circ} \mathrm{C}($ Fig. $7 \mathrm{c})$. Both investigated steels gave similar impact toughness results, having $34 \mathrm{~J} / \mathrm{cm}^{2}$ transition temperatures in the range of $-64^{\circ} \mathrm{C}$ to $-68^{\circ} \mathrm{C}$. The $\mathrm{Nb}-\mathrm{Mo}$ steel had slightly lower upper shelf energy due to its higher tensile strength, although at the same time the $34 \mathrm{~J} / \mathrm{cm}^{2}$ transition temperature was slightly lower. Previous studies have shown that the impact transition temperature is controlled by the largest grains in the grain size distribution, where grain size refers to the ECD of grains with grain boundary misorientations $>15^{\circ}$, for example $\mathrm{d} 90 \% .^{20,21}$ By alloying with $\mathrm{Nb}-\mathrm{Mo}$, a pancaked austenite structure was achieved after hot rolling, which then produced a finer and more uniform prior austenite structure after re-austenitization, presumably due to the presence of more nucleation sites for austenite grains. This led to a finer martensitic structure with higher strength and better impact toughness.

\section{SUMMARY AND CONCLUSION}

This article contains the results of an investigation into the effect of molybdenum and niobium on the microstructures and mechanical properties of laboratory-control rolled and direct quenched steels. The two studied compositions were based on grade 22MnB5 (0.22C-1.2Mn) with additions of $0.05 \mathrm{wt} . \%$ $\mathrm{Nb}$ and two Mo levels of 0 wt.\% and 0.15 wt.\%. After controlled rolling with a finish rolling temperature of $850^{\circ} \mathrm{C}$ and direct quenching, the 8-mm-thick strips were re-austenitized and quenched at $\sim 80^{\circ}$ $\mathrm{C} / \mathrm{s}$ to simulate press hardening. The results led to the following conclusions:
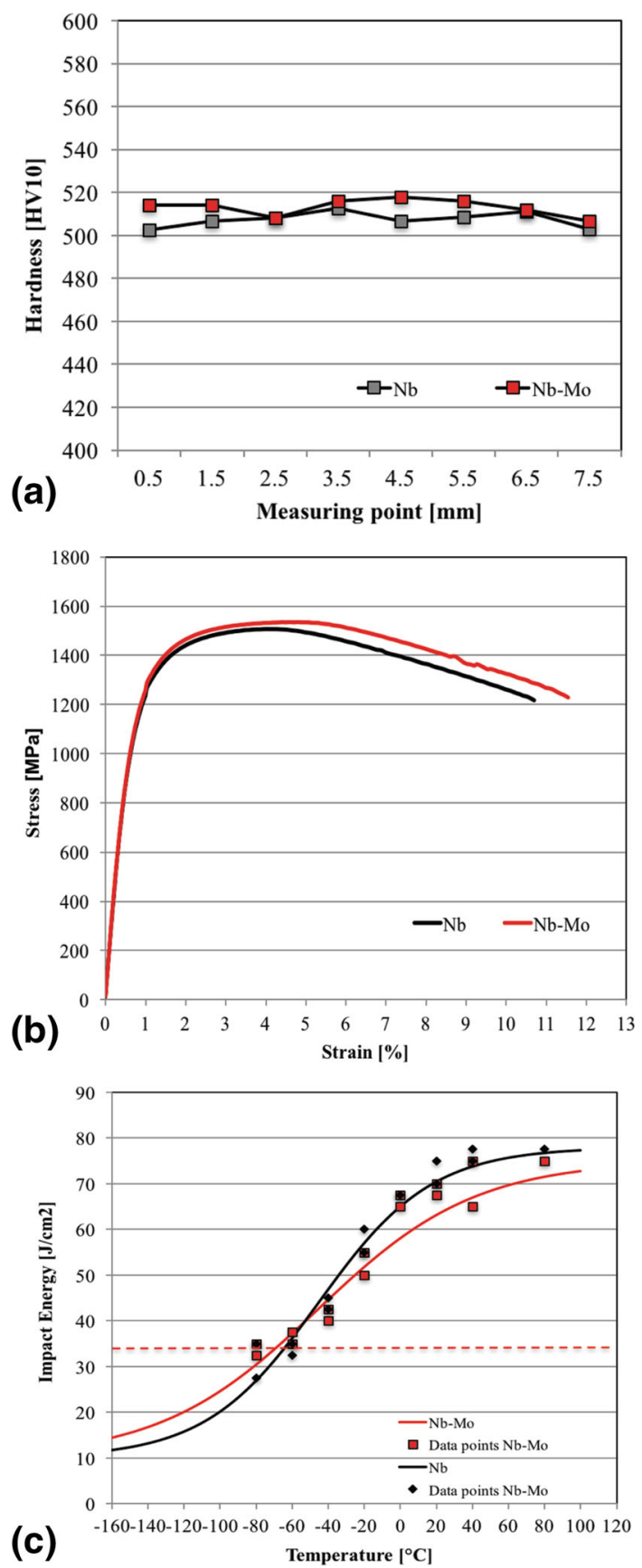

Fig. 7. (a) Hardness profiles through the thickness of the samples; (b) stress-strain curves of the investigated steels; (c) transition curves based on longitudinal Charpy V-notch test results (tanh fitted).

1. Nb-Mo microalloying allows lower cooling rates to achieve a fully martensitic microstructure, which could mean an easier press hardening process and higher plate thicknesses. CCT diagrams show that Nb-Mo microalloying delayed the formation of ferrite and bainite compared with $\mathrm{Nb}$ microalloying alone. This was especially so in the case of deformed, unrecrystallized austenite, when cooling at $20^{\circ} \mathrm{C} / \mathrm{s}$ resulted in a hardness $>500 \mathrm{HV} 10$. 
2. After reaustenitization and water quenching, EBSD analysis showed that a smaller and more uniform grain structure was achieved with $\mathrm{Nb}$ Mo microalloying rather than $\mathrm{Nb}$ microalloying alone. Grain misorientation distributions were typical of fully martensitic microstructures with no difference between the two investigated steels.

3. More than $1500 \mathrm{MPa}$ tensile strength and $\sim 11 \%$ of total elongation were achieved in tensile testing with both investigated steels combined with $34 \mathrm{~J} / \mathrm{cm}^{2}$ transition temperatures of $\sim-65^{\circ} \mathrm{C}$ after re-austenitization and water quenching. Improved mechanical properties were achieved in the case of Nb-Mo alloying because of refinement of the martensitic microstructure.

\section{ACKNOWLEDGEMENTS}

Open access funding provided by University of Oulu including Oulu University Hospital. The financial support of the SSAB Europe Oy is gratefully acknowledged.

\section{OPEN ACCESS}

This article is distributed under the terms of the Creative Commons Attribution 4.0 International License (http://creativecommons.org/licenses/by/4.0/ ), which permits unrestricted use, distribution, and reproduction in any medium, provided you give appropriate credit to the original author(s) and the source, provide a link to the Creative Commons license, and indicate if changes were made.

\section{REFERENCES}

1. J. Wang, C. Enloe, J. Singh, and C. Horvath, SAE Int. J. Mater. Manuf. 9, 48 (2016).
2. R. Kuziak, R. Kawalla, and S. Waengler, Arch. Civ. Mech. Eng. 8, 103 (2008).

3. C. Wang, M. Wang, J. Shi, W. Hui, and H. Dong, Scripta Mater. 58, 492 (2008).

4. A. Kaijalainen, P. Suikkanen, T. Limnell, L. Karjalainen, J. Kömi, and D. Porter, J. Alloys Compd. 577, 642 (2013).

5. S. Morito, H. Yoshida, T. Maki, and X. Huang, Mater. Sci. Eng. A 438-440, 237 (2006).

6. A.J. DeArdo, Fundamental Metallurgy of Niobium in Steel, Nb Science and Technology (Warrendale: TMS, 2001), pp. 427-478.

7. M. Masimov and N. Kwiaton, A study of Mo-induced bainitic transformation in continuously cooled steels by X-ray and electron diffraction, Euromat 2009, Glasgow.

8. S. Wang and P. Kao, J. Mater. Sci. 28, 5196 (1993).

9. T. Hara, H. Asahi, R. Uemori, and H. Tamehiro, ISIJ Int. 44, 1431 (2004).

10. M.G. Akben, B. Bacroix, and J. Jonas, Acta Metall. 29, 111 (1981).

11. ISO 6892-1:2009 standard for tensile testing.

12. European Standard EN 10045-1:1990 E, Metallic Materials-Charpy Impact Test-Part 1: Test Method, March 1990.

13. M. Militzer, F. Fazeli, T. Jia, Fundamentals and Applications of Mo and Nb in High Performance Steels, vol. 1, ed. Hardy Mohrbacher (CBMM, IMOA and TMS, 2014), p. 23-36.

14. P.A. Manohar, D.P. Dunne, T. Chandra, and C.R. Killmore, Iron Steel Inst. Jpn. Int. 36, 194 (1996).

15. N. Isasti, D. Jorge-Badiola, M.L. Taheri, B. Lopez, and P. Uranga, Metall. Mater. Trans. A 42, 3729 (2011).

16. K. Junhua, Z. Lin, G. Bin, L. Pinghe, W. Aihua, and X. Changsheng, Mater. Des. 25, 723 (2004).

17. F. Xiao, Y. Cao, G. Qiao, X. Zhang, and B. Liao, J. Iron. Steel Res. Int. 19, 52 (2012)

18. X. Sun, Z. Li, Q. Yong, Z. Yang, H. Dong, and Y. Weng, Sci. China Technol. Sci. 55, 1797 (2012).

19. S. Zajac, C. Schwinn, and K.H. Tacke, Mater. Sci. Forum 500-501, 387 (2005)

20. J. Hannula, J. Kömi, D.A. Porter, M.C. Somani, A. Kaijalainen, P. Suikkanen, J.-R. Yang, and S.-P. Tsai, Metall. Mater. Trans. A 48, 1 (2017).

21. S. Pallaspuro, A. Kaijalainen, S. Mehtonen, J. Kömi, Z Zhang, and D. Porter, Mater. Sci. Eng., A 712, 671 (2018).

Publisher's Note Springer Nature remains neutral with regard to jurisdictional claims in published maps and institutional affiliations. 